УДК: 7.032'02"'-5/-4"(38), 72.014.4, 72.04.013

ББК: $85.110,5$

DOI: $10.18688 /$ aa2111-01-12

J.des Courtils

\title{
New Approaches to Ancient Greek Architecture ${ }^{1}$
}

This paper focusses on the Greek temple. Obviously, the Greeks were not the only ones to build temples: before them, there were the Sumerians, the Egyptians, the Babylonians. So to speak, all the great and small peoples of the Near East had led the way, followed by the Etruscans, Romans, Gauls, and many other peoples all over the world. All these buildings, scattered over time and space, have more or less the same function: to shelter the divinity or its effigy. I will therefore try to explain what makes the Greek temple so original, namely its form. Along the way, I hope to show that the Greeks implemented simple, not to say simplistic, or even rudimentary construction processes in the service of "standardised" architecture (with all the pejorative connotations of this word), but architecture is animated - at least in the most accomplished examples - by the sense of proportion, geometrical vision, and conceptual research that the moderns endeavour to detect and explain. Its study outline that I am going to propose aims to be, on my part, a humble tribute to the "Greek genius", an outdated and perhaps erroneous formula but to which, after a few decades of reflection, I persist in adhering with fervour and conviction.

The first observation is obvious: just as it is easy for (almost) everyone to recognize a Gothic or Baroque church, it is easy to recognize a Greek temple. This is not only due to the simplicity of its architecture. Let us consider an example of the most widespread Doric style, the temple of Hera II at Paestum (Ill. 14). The columns, the simple capitals and the frieze with its triglyphs and metopes, the triangular pediment are easily recognizable because they are immutable elements of this style.

But the stability of the latter is not limited to the upper part of the building: the overall design of the building, the number and distribution of the columns, are also, with a few rare exceptions, immutable. For example, a Doric Greek temple normally has 6 columns on the façade and 13 columns on the long sides (with a margin that allows for a variation from 11 to 15). Finally, since the front and rear façades are strictly identical, the Greek temple uniformly presents the same appearance whether viewed from the front or from the rear.

However, it must be recognized that a Greek temple is, in fact, only made up of blocks placed one on top of the other, as in a children's construction game, strictly obeying the laws of gravity and drawing a simple and orthogonal network of horizontal and vertical lines. The rows of columns supporting entablature are known as the "post and lintel" system. But, contrary to the materials themselves, the resistance of the materials is an unbreakable law. The limestone

1 I would like to express my warm gratitude to Nazehda Nalimova for inviting me to deliver a paper on the occasion of this great conference. 
used by the Greeks is a brittle material and even if marble is used, which has high density and strength, it is not possible to indefinitely lengthen stone beams arranged horizontally above the void and loaded with the full weight of the upper parts and the roof. The Greeks were aware of that physical limit, but they did not know how to calculate it as modern-day engineers do. Hence the extreme caution led them to be very timid: the intervals between the columns were quite small, the horizontal beams - the architraves - were quite often either exaggeratedly thick or shorter than it was physically necessary (and sometime both). This inevitably led to the construction of small and medium-sized buildings. To take just a few examples, summarized on the following table: The temple of Paestum is $24 \mathrm{~m}$ wide, the Parthenon, considered as a large temple, is almost $31 \mathrm{~m}$ wide, but what is it next to the $144 \mathrm{~m}$ wide St Peter's Basilica (almost 5 times more than the Parthenon)? Same observation concerning the length of these buildings (respectively $69 \mathrm{~m}, 69 \mathrm{~m} 50$ and $219 \mathrm{~m}$ ). If we compare the heights, we obtain results of the same order.

\begin{tabular}{|l|c|c|}
\hline \multicolumn{1}{|c|}{ Measurements in meters } & Width & Length \\
\hline Paestum (Hera) & 24,26 & 60 \\
\hline Parthenon & 30,88 & 69,50 \\
\hline Milano, Duomo & & 158 \\
\hline St Peter & 144 & 219 \\
\hline
\end{tabular}

Moreover, although they had discovered the principle of the arch and vault in the time of Alexander the Great, the Greeks made very timid use of it because they were unable to master its constraints, as did the Romans and their modern successors.

To this timidity, even incapacity, respect for a form as a further explanation, a constant in the art and civilization of the Greeks, is probably to be added. Over time, the formal characteristics of Greek architecture, inherited from the primitive period of wooden architecture, have become almost impregnable laws. On the contrary, the Romans and the moderns demonstrated a freedom in this respect, which the Greeks denied themselves. This arcature (Ill. 15), adorned with a purely decorative entablature imitating a Doric frieze with triglyphs and metopes, would have been, in the eyes of an ancient Greek, an unbearable heresy. However, this must not lead to think that it is only the technical constraints already mentioned that led the Greeks to build small (in Asia Minor, in continental Greece, in Sicily) temples do display very large dimensions, even if they remain behind the modern giants already mentioned, to which can be added most of the Gothic cathedrals. In fact, the appearance and dimensions of the biggest Greek temples are broadly comparable to those of the Madeleine church in Paris, which is not insignificant, but far from the gigantism of the cathedrals. Still, there is a deeper and more interesting reason for the limitation generally observed in the dimensions of Greek temples: this reason must be sought in the way of thinking of the ancient Greeks. Blaise Pascal summed up one aspect of this question perfectly in one of his Pensées (1717): "I confess that one of the things that has charmed me most in the works of the ancients is that they catch the great and the simple at the same time, instead of it almost always happening that our moderns, in seeking the great, lose 
the simple, or in seeking the simple, lose the great". Obviously, Pascal was not talking about greatness in the material sense, but about greatness in the abstract or moral sense.

The sense of measure that characterises ancient Greek civilisation is concentrated in a famous verse by Aeschyles, "metron to beltiston" (Agamemnon, v. 378), which could be translated as "moderation is the greatest of qualities". The Greek loved moderation and abhorred hybris, that is to say, excess. As this principle of moderation have been established, I would now like to briefly retrace the genesis of the Greek temple with the purpose of extracting from this history some principles which will, I believe, shed some light on the very essence of this architecture.

The beginnings of Greek architecture are modest: the first buildings of any importance must have been built in the same way as fragile and modest constructions that can still be seen in various parts of the world, for instance in Turkey, or in Yemen. The materials used were mud brick (an excellent material) and wood, the latter making it possible to consolidate the walls and to directly support, by means of posts, the weight of the heavy roof covered with clay. Archaeology confirms this hypothetical genealogy: the British excavations at Lefkandi, on the island of Evia, uncovered the remains of a very large building (more than $50 \mathrm{~m}$ long) made entirely of mud brick and wood and covered with a high gable roof. In order to prevent rainwater run-off from splashing on the walls and melting the mud-brick walls, the roof was extended well beyond the plumbing of the walls, which necessitated the installation of a peripheral row of posts, thus forming a peripheral gallery, a configuration found elsewhere, both in ancient Gaul and in more recent buildings such as churches in Romania. As a matter of fact, the primitive building in Lefkandi is the already formed embryo of the Greek temple: a gable roof that calls the pediment to the façade and a colonnade (then in wood, later in stone) all around the building.

However, there is no inevitability in the history of architecture, or in history itself... The way in which the wooden post was to become a column was not written. However, in the space of one or two generations, around the middle of the $6^{\text {th }}$ century B.C., the Greeks transformed this post into a column and a capital with precise and immutable shapes, to which they added other elements, also stereotyped (the entablature), which were adopted by all and thus gave rise to the famous Doric and Ionic orders, with all that the word order implies of standardisation, that is to say norms, therefore constraints and also uniformity.

The development of these orders was largely due to a precise, identifiable and indisputable external influence, that of Egyptian art, as shown by the so-called "proto-doric" columns of certain Egyptian temples (Deir el-Bahari), the name of which is moreover an anachronism, since at the time when the Egyptians built them, Doric still did not exist anywhere. How, one might ask, could this loan have been passed from the Egyptians to the Greeks? The answer to this question can be summed up in one word: "Naucratis".

Naucratis is a settlement in the Nile delta, created by the Greeks in the $7^{\text {th }}$ century BC and roughly comparable to the foreign concessions of the $19^{\text {th }}$ and $20^{\text {th }}$ centuries in China. For several centuries, the Greeks maintained there a real Greek city with its houses, its religious sanctuaries, and its harbour which enjoyed an extra-territorial status and which was, as they say, a "bridgehead" in Egypt. It allowed Greek navigators, merchants, travellers, and craftsmen to discover the already ancient civilisation of the land of the pharaohs. The best testimony of these contacts is that of the "father of History", Herodotus who, in the $5^{\text {th }}$ century BC, passed through Naucratis and travelled to the rest of Egypt. 
In Egypt, the Greeks were able to observe the techniques of cutting and assembling stones shaped into huge but regular blocks. They therefore saw stone colonnades, capitals, and entablatures made of stone rather than wooden beams. However, apart from the already mentioned example of Deir el-Bahari, one may legitimately wonder whether their influence on the Greeks was so strong, for the observation of the constituent elements of Egyptian architecture does not seem to reveal any formal elements (such as triglyphs or dentils) likely to give rise to the Greek orders. This is where the so-called genius of Greek civilization comes into play: namely, the ability to borrow ideas which, by moving on to material realization, will receive a new, original, purely Greek form.

To show this, I will begin by taking a diversion through sculpture, where the same process can be observed. In Greece, the period of the birth of stone architecture is also that of stone sculpture, which multiplies male statues in frontal position, there too (as for the Greek temple) an immutable, indefinitely repeated stereotype that specialists call the kouros. The confrontation between the Greek kouros and one of the countless Egyptian statues speaks for itself: the Greek statue takes up the structural principles of the Egyptian one, of which it is obviously the transposition, but it is also obvious, if I may make this crude simplification, that the Greek is a Greek, and the Egyptian an Egyptian, to the point that only a precise analysis and comparison can show that the Greek sculptor took up the idea of the male statue in stone and its general form, but gave it a style that is properly the Greek trademark.

The same analysis scheme will be followed with regard to architecture. We have seen that the general shape of the Greek temple was in germ in the wooden constructions of the most ancient times. The contact with Egypt was a kind of fertilization: the Greeks learned the art of cutting stone into regular blocks, the art of stacking the blocks, of cutting cylindrical blocks in order to make column drums, but also the art of binding the blocks together with metal staples, making the use of cement unnecessary and ensuring the building an effective defence against earthquakes. All this comes from Egypt, but on all of this the Greeks have, so to speak, put on a Greek dress which makes it impossible to confuse a Greek temple with an Egyptian one, as in the case of the Egyptian statues and their Greek counterpart. I will also point out a structural difference that has a certain importance: the colonnades of Egyptian temples are always inside the buildings or circumscribed alongside the inner courtyards, whereas the Greeks generously spread their colonnades outside the temples, giving them precisely the appearance which is recognisable at first glance.

Now that the Greek temple has been born, I would like, finally, to get to the heart of my subject and contemplate the temple no longer in its genesis or evolution, but in its very concept and realisation: how the Greek temple is built and how can the study of the completed building reveal to us the process by which the architect drew up the project?

Concerning the construction of the temple itself, I will leave aside the financial aspects, the organisation of the building site and the successive stages which see the craftsmen cutting and roughing the blocks at the quarry, transporting them to the building site, finishing, cladding, laying, and sealing with metal staples. All this is well known to us thanks to archaeology, to quantities of written documents (building estimates, craftsmen's pay) and to the observation of the preserved buildings, especially those that are partially ruined and thus reveal their in- 
nards... I would like to insist on the DIY (do-it-yourself) aspects to better illuminate, by contrast, the incredible perfection of the final result.

Why talk about do-it-yourself? Because in ancient times, quarrymen, stonecutters, and sculptors had rudimentary technical means at their disposal and did, in the noble sense of the word, DIY. Their tools hardly changed until the $21^{\text {st }}$ century: they were quarrymen's picks, chisels, and, in particular, toothed chisels, metal points, mallets, and hammers, which could be flat or pointed. If stone is usually hard, marble is very hard. Therefore, percussion instruments had to be used, past and present. The only difference between yesterday and today is that today percussion is no longer based solely on human strength but on the energy supplied by a compressor.

The stonemasons had to cut blocks with perfectly regular shapes and extremely precise dimensions: a wall like the one of the buildings of the Athenian acropolis could not suffer from the slightest imperfection; the size of each block had to be accurate to a tenth of a millimetre. The work is all more difficult because underneath the apparent simplicity lies the first difficulty: in many cases, the height of the blocks, which appears to be rigorously identical, decreases from the bottom to the top of the wall. Moreover, the wall, just like the column, tapers imperceptibly from bottom to top, so that the thickness of the blocks decreases progressively and more precisely that each block of the wall, as well as each column drum, will be very slightly narrower at the top than at the bottom... What means of measurement were available to the workers to respect these decreases?

In order to answer this question, it is necessary to know the units of measurement of the Ancients and how they were used. Let us look at the units of measurement: 1 foot of about $30 \mathrm{~cm}$ divided into 16 dactyls. Like the French foot before the French Revolution, the Greek foot had regional variations. Each architect therefore necessarily had with him a ruler, probably made of bronze, measuring one foot: this ruler, placed in an accessible part of the building site, served as a reference for all the workers on the site and thus guaranteed the consistency of the measurements, impossible to ensure otherwise if the building site combined an architect, contractors and workers from different regions, each of whom would have used the foot of his region. This ruler was called kanon.

But why divide the foot into 16 dactyls, and not 12 (or even 10!) and how did the workers make use of the rule brought by the architect? To these two questions, there is one obvious answer: a piece of string! Each worker takes a piece of string, cuts it to the exact measure of the architect's kanon and can thus carry it to every point on the building site. If he needs to measure half a foot, he will bend the string in half. He will bend it a second time to get a quarter foot, a third time to get an eighth foot and again to get a sixteenth foot, that is to say... one dactyl! Almost without knowing how to count, any stonemason could thus take precise measurements. Still it is obvious that some blocks required even finer measurements, up to a tenth of a millimetre. One wonders how the men did it, especially as the Greek numbering system was of an apparent simplicity that hides a profound absurdity or rather a total lack of practicality: each prime number, tens, and hundreds were, in fact, designated by a letter of the alphabet... The only solution was to resort to drawing or, even better, to making a life-size model that the craftsman will only have to reproduce exactly.

But let us move on to the concrete observation of an ancient building, and not the least important one: the temple of Zeus in Olympia, which housed nothing less than the statue of 
Zeus in gold and ivory, the work of Phidias, considered from ancient times as one of the seven wonders of the world. If this statue has totally disappeared, and it is easy to understand why, the remains of the temple are, fortunately, abundant enough for us to be able to restore it down to the last detail. We preserve the sculptures of its two pediments and enough blocks of architecture to be able to propose a safe restitution of the whole elevation.

The constituent elements of this temple have all been created by means of whole feet and their multiplication, a system summarized as follows:

Width of one roof tile $=2$ feet

Length of one architrave block $=8$ feet

Interaxial distance of columns $=8$ feet

Column height $=16$ feet

Width of naves of the cella : central nave $=12$ feet ; side naves $=10$ feet each.

This modular system, to tell the truth, did not require a great deal of design effort on the part of the architect, since he was content to multiply the foot as many times as necessary! From a construction point of view, it is therefore a simple and satisfactory system. From the point of view of the building design, this process has two surprising effects : the first is that the total dimensions of the building could not be predicted before it was either drawn or built up, because they can only be established a posteriori, by adding up the measurements of each part; the second, also somewhat surprising and following from the first, is that the proportions of the building are not predictable either, since the proportions can only be calculated once the measurements of the whole and those of the parts have been established. But it is conceivable that the Greek architects, handicapped by the complexity of the numbering system at their disposal, preferred to proceed as did the architect at Olympia by adding or even multiplying a basic unit, rather than by dividing the general dimensions of the building.

Cause or consequence of the difficulty of using this numbering system, the Greeks looked for and found a parry which is also indicative of a certain kind of spirit. A recent discovery has indeed revealed the existence of a process that I would describe as brilliant, and which shows that the Greeks made more use of geometry than arithmetic. The Temple of Didyma, in Asia Minor, has preserved intact whole sections of walls, made of marble blocks that are wonderfully matched and perfectly smooth. Being perhaps the millionth visitor to walk past them and doing so himself for the thousandth time, a German architect by the name of Lothar Haselberger had his eye caught by a detail, revealed by a curling ray of sunlight on the surface of the wall, which enabled him to distinguish the existence of an extremely fine incision, as if made with a razor, but also having the peculiarity of being long and absolutely straight, therefore made by human hands. To his great surprise, he was able to follow it over the surface of several blocks for several metres! He then discovered a whole network of lines, some straight, parallel or perpendicular to each other, others curved, some drawing strange figures. A meticulous and systematic survey allowed him to see that these were drawings of the architectural elements of the temple [4].

These drawings revealed "tricks" that explain the perfect realisation of the most complicated and apparently less feasible elements of the temple. I will take just one example, that of the columns. Everyone knows that the columns of Greek temples were slightly thinning from bottom to top, but that is not all: this thinning was combined with a very slight bulge that makes them look like skittles, but with a much less pronounced curvature. The problem, in a temple 
whose columns are 18 metres high and are made of superimposed drums, is to ensure that the curvature of the column is perfectly regular and that the curvature will be rigorously identical on all the columns - and it was planned that there would be more than a hundred (120 to be exact)! How one provides the workers with the dimensions of each drum on each column? This is impossible and this is not how the architect proceeded. He drew two drawings on the wall of the temple: on the first one, a semicircle represents half of the lower bed of the column with the tracing of rays indicating the location of the flutes. The angle between the flutes can be transferred to the lower and upper bed of the flutes to allow the flutes to be cut. A second drawing is even more subtle and represents the column cut in two from top to bottom along its axis. The radius is drawn at its actual size while the height of the column is shown on a scale of $1 / 16$. As the column tapers from bottom to top, two lines in the drawing connect the ends of the lower and upper radii. On this line, the architect has drawn an arch which is a full-scale drawing of the radius of the column from the base to the top. The short cut in height is, as we have seen, $1 / 16$, which obviously corresponds to the ratio between the antique dactyl and foot. Each worker can thus go and "grasp" with his string the length of the radius, and he will only have to multiply it by 16 to obtain the real diameter at any height of the column, since, each dactyl on the drawing will correspond to a foot in reality. As the construction of the temple of Didyma took place over several centuries due to its enormous dimensions and financial problems, the workers were provided with plans and drawings whose preservation was guaranteed by their incision in the marble of the building itself!

Finally, I would like to comment on some aspects of three remarkable, exceptional buildings which, for this reason, are not representative of the whole of Greek architecture, but which have the merit of giving an idea of the degree of elaboration of the latter, despite the technical and intellectual limits and constraints mentioned above. The first building is the Theatre of Epidaurus, the second is the Parthenon, and the third, almost unknown, is called the Treasure of Cyrene and was built in Delphi.

The Theatre of Epidaurus is the best preserved of antiquity. I will comment neither on the poetry of the site nor on the perfection of the lines of the building, nor even on the exceptional quality of the architect and the builders who knew how to achieve these curves of perfect regularity. I will content myself with a remark made by Jean Bousquet a long time ago [2]: as this scholar brilliantly noticed, the number of steps (21 at the top, 34 at the bottom, total 55) corresponds to three consecutive numbers from the famous Fibonacci mathematical sequence.

The Parthenon needs no introduction. This magnificent building is currently undergoing the final stage of a remarkable restoration programme that will restore it to some of its lost splendour. The first characteristic I would like to point out is that, contrary to appearances, there are nearly no straight lines or right angles in this temple: the platform on which the temple rises is domed, so that the shape of each column had to be corrected to prevent them from yawning in a fan shape. Now it is usual for the columns of a temple to be very slightly tilted inwards: the correction had to take this additional constraint into account. But, second characteristic, all this had the effect that the blocks of the platform and those of the entablature had to be corrected: instead of being perfect parallelepipeds, they had to be cut in the shape of parallelograms to prevent their joints from yawning. Incidentally, I note that these blocks, like the drums of columns which weighed about 9 tons, or the blocks of architraves, which were even heavier, 
had to be cut to the exact millimetre, handled, hoisted, and placed with extreme care: they had the weight of marble, but the fragility of a crystal, so that the slightest shock on an edge or face of the blocks could prove catastrophic. The slightest defect on the bright white Athenian marble became, in the sun of Hellade, an unbearable stain which would lead to the block being rejected... These non-orthogonal blocks used in the construction of a building with curved lines therefore defy the laws of design, optics and almost common sense: the Parthenon appears to consist of a network of

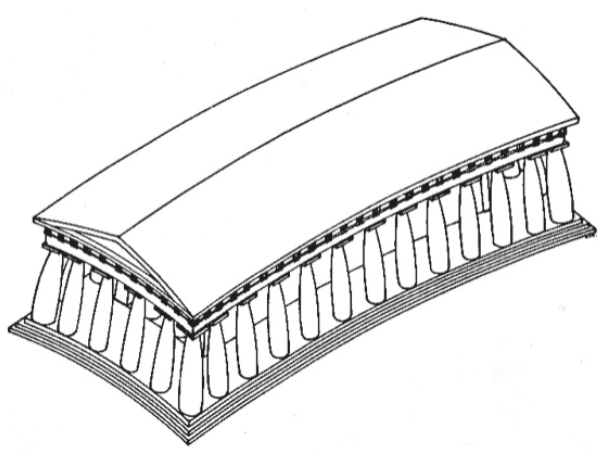

Fig. 1. Drawing of the Parthenon with exaggerated optical refinements. From: J.-J. Coulton, 1982 [3, fig. 44] straight lines intersecting at right angles, but this is only an illusion (Fig. 1). Still, in this play between appearances and reality hides another, much more subtle reality...

It has long been observed that the extreme dimensions of the Parthenon are in a remarkable ratio of $4 / 9$ or $9 / 4$ to each other. The width is in the situation of being the proportional average between the height and the length of the building. This ratio of $4 / 9$ is also the ratio of the column diameter and centre distance, as well as the ratio length/width of the cella walls (without the antes).

How did the architect achieve this goal? After much research and trial and error, it is assumed that he used a module of 10 dactyl $(19.2 \mathrm{~cm})$. In fact, the dimensions of the members of the Parthenon correspond to whole multiples of this module: the shaft of the column is 50 modules high (without the capital), the architrave and the frieze are each 7 modules high, the inside width of the cella is 100 modules, etc. Research has also brought to light the use of the number phi, or golden section, or golden number, whose arithmetic expression is 1.618: the cella, 100 modules wide, is 160 modules long, so that the ratio $1 / \mathrm{L}$ is very close to phi. Without going further into geometric observations where one would quickly get lost, we can draw an important conclusion from these observations. Indeed, we are led to establish that the architect has made the Parthenon part of an extremely elaborate network of proportions that define its extreme dimensions but also the dimensions of many of its members, whether in terms of length, diameter or height.

If we compare this conclusion with the one we made earlier about the Temple of Zeus at Olympia, we see that the abyss separates the architects of these two temples: the architect of Olympia was content to take as a module the measure of the foot and multiplied it as many times as he thought fit to design the various elements of the Temple of Zeus whose overall dimensions are, unsurprisingly, the sum of their parts. But Ictinos, the architect of the Parthenon, imposed on the whole as well as on the parts of his temple a system of pre-established proportions into which the building had to fit. For him, the proportions were most important! We notice, moreover, that the module that the Greek foot of 16 dactyls is in the proportion of $16 / 10$ in relation to the module of 10 dactyls he used, a proportion which is expressed by the number 1.6, an excellent approximation of the golden ratio! In other words, Ictinos has made 
the Parthenon a geometric construction based on this precise proportion, whose qualities are known and recognised.

We still have one last step to take, both the least difficult and the most difficult... I would like to briefly present to you some observations made by Jean Bousquet on the Treasure of Cyrene [1], a small building built in Delphi a hundred years after the Parthenon by the inhabitants of the Greek city of Cyrene, in Libya, the homeland, among others, of the famous Simon of Cyrene who appears briefly in the Gospels to help Christ carry his cross to the summit of Golgotha. Don't look for this building in your memories of your visit to Delphi, it no longer exists: Jean Bousquet studied this dismembered building by means of a few dozen blocks that he identified, brought together and measured with admirable precision, helped in this by the fact that these blocks, made of marble, still had been perfectly preserved and therefore faces and planes were measurable.

Jean Bousquet was a great archaeologist, fortunately enough he was also an excellent mathematician. Studying the treasure of Cyrene, he scrutinised its measurements in the hope of finding ratios of proportion revealing the drawing procedure followed by the architect. He found them and then realised that chance had led him to work on one of the most extraordinary buildings in Greek architecture! Here is a table showing the beginning of an astonishing chain of findings. Since the measurements taken on the blocks of the building are perfectly safe, the presence of these mathematical relationships can be explained in two ways: either it was chance, or the architect consciously wanted to bring his construction into a network of relationships. I insist on this point: it is not a question of numbers, of sizes, but of relationships between numbers or sizes. But we can go further: J. Bousquet indeed pointed out that Plato had twice gone to Cyrene to meet a famous mathematician named Theodore. You know that Plato's work is permeated with mathematics: thanks to it, we know the main problems that the mathematicians of his time were facing and which I have summarised in the following table. Most of these problems were studied by Theodore and his school in Cyrene. They were "in the air of the times". We also know that Greek architects had a solid mathematical background. What is surprising, therefore, is that the treasure built by the inhabitants of Cyrene in honour of Apollo in Delphi is a sort of petrification of the mathematical problems of his time. For instance, Jean Bousquet showed that the ratio between the surface area of the lower circle of the column and that of the upper circle was exactly in the ratio of 3 to 2 , which is remarkable, as we know that the Greeks were not able to measure the surface area of a circle!

Let us go further: it is more than a petrification of problems, it is a petrification of their solution! Indeed, if the Greeks were unable to express arithmetically the value of the roots or the number pi, they showed themselves perfectly capable of constructing them geometrically in the marble of the treasure of Cyrene: actually, you may not be able to calculate the sides of a triangle but still be able to draw it. The Greek stonemasons probably did not know how to make complicated calculations, but they were able to copy a geometric model, drawn or already sculpted, to perfection. Design and geometry are therefore the two pillars of ancient Greek architecture. 


\section{References}

1. Bousquet J. Le trésor de Cyrène. Bousquet J. Fouilles de Delphes, vol.2. Paris, De Boccard Publ., 1952. 113 p. (in French).

2. Bousquet J. Harmonie au théâtre d'Épidaure. Revue Archéologique, 1953, vol.41, pp.41-49 (in French).

3. Haselberger L. Aspekte der Bauzeichnungen von Didyma. Revue Archéologique, 1991, vol. 79, pp. 99-113 (in German).

4. Coulton J.-J. Ancient Greek Architects at Work: Problems of Structure and Design. New York, Cornell University Press Publ., 1982. 208 p.

Title. New Approaches to Ancient Greek Architecture

Author. des Courtils, Jacques - Professor Emeritus. Bordeaux-Montaigne University, Ausonius Laboratory, 33607 Pessac Cedex, France. jacques.des-courtils@u-bordeaux-montaigne.fr ORCID: 0000-0003-1769-2659

Abstract. The goal of this paper is to explore some of the modern approaches to ancient architecture, by studying first technical devices used in it. Second, one can detect different conceptions of architecture that have led to apparently similar constructions but in which the intervention of architects with very different skills can be discerned. Not many scholars ventured to study the building processes and the proportions of ancient Greek buildings. Among others, it is fair to mention J. Bousquet, J.-J.Coulton, L. Haselberger. Planning and building are two logical steps that seem to follow one another naturally but the reality is more complex: observing the hesitations of ancient builders that have left their marks in some of their buildings and new discoveries about the graphic processes they made use of, may lead to reconsidering to some extent our knowledge of ancient Greek architecture. The study of Greek architecture leads first to consider the techniques used by the ancients. We realize that these were particularly rudimentary, but the quality of the work led to almost perfect results, despite the rigor of the materials. In the same way, the study of plans and proportions allows to define a whole arc of processes. Some buildings are the result of a simplistic construction in which only elementary rules of construction and decoration were applied. Other buildings, on the contrary, were built according to a pre-established plan whose analysis reveals the presence of elaborate geometric proportions. The implementation of the latter is obviously a feat that is only found in a few exceptional buildings.

Keywords: Greek architecture, temple, Doric order, proportions, planning, measurement unit

Название статьи. Новые подходы к древнегреческой архитектуре

Сведения об авторе. Де Куртиль Жак - почётный профессор. Университет Бордо-Монтень, Лаборатория Аусониуса, 33607 Пессак-Седекс, Франция. jacques.des-courtils@u-bordeaux-montaigne.fr ORCID: 0000-0003-1769-2659

Аннотация. Цель данной статьи - показать некоторые современные подходы к древней архитектуре, изучив первые технические устройства, используемые в ней. Кроме того, можно обнаружить различные концепции архитектуры, которые привели к внешне схожим конструкциям, но в которых можно различить вмешательство архитекторов с очень разными навыками. Не многие учёные отваживались изучать строительные процессы и пропорции древнегреческих зданий. Среди других справедливо упомянуть Ж. Буске, Ж.-Ж. Коултона, Л. Хазельбергера. Проектирование и строительство - это два логических шага, которые, кажется, естественным образом следуют друг за другом, но реальность более сложна: пролеживаемые сомнения древних строителей, которые оставили свои следы в некоторых зданиях, и новые открытия о графических приёмах, которые они использовали, могут в некоторой степени привести к пересмотру наших знаний о древнегреческой архитектуре. Изучение греческой архитектуры приводит в первую очередь к рассмотрению строительных методов, используемых древними. Мы понимаем, что они были достаточно примитивными, однако качество работ приводило к почти идеальному результату, несмотря на сопротивление материалов. Точно так же изучение планов и пропорций позволяет нам реконструировать целый ряд процессов. Некоторые сооружения являются результатом упрощённого строительства, в котором применялись лишь элементарные правила возведения и отделки. Другие здания, напротив, были построены в соответствии с заранее установленным планом, анализ которого показывает наличие сложных геометрических пропорций. Их применение, очевидно, является важным свершением и встречается только в нескольких исключительных памятниках.

Ключевые слова: древнегреческая архитектура, храм, дорический ордер, пропорции, планировка, единица измерения 


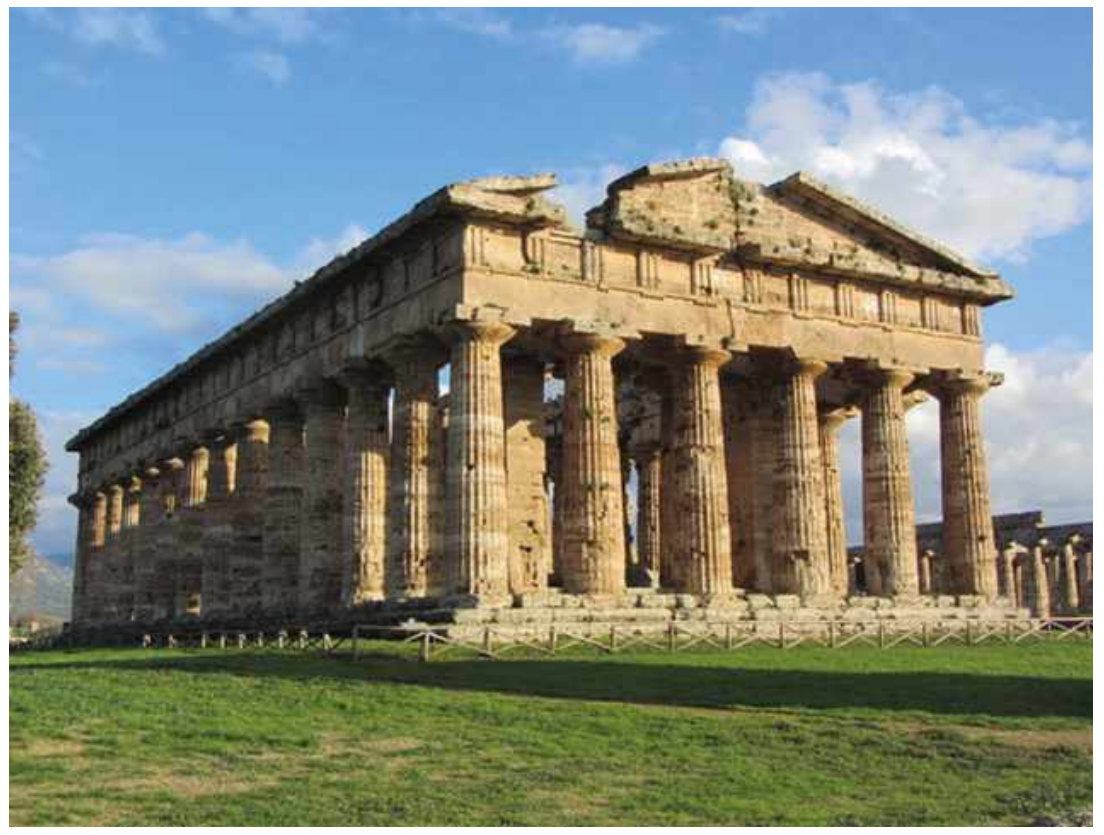

Ill. 14. Paestum, second temple of Hera. Photo by Jacques des Courtils

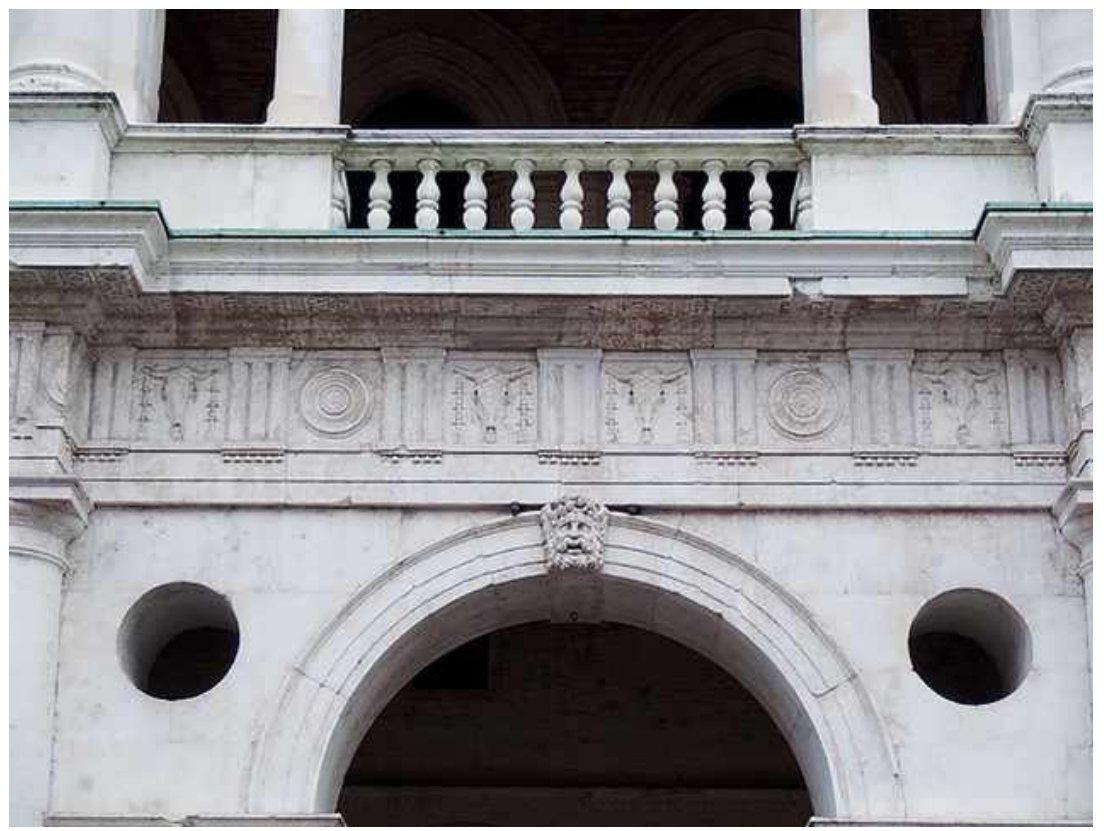

Ill. 15. Vicenza, Basilica Palladiana. Photo by Jacques des Courtils 